\title{
The Analysis of the Informatics Exam of Secondary Education in Lithuania
}

\author{
Liudvikas KAKLAUSKAS, Vilma NARKIENĖ \\ Siauliai University \\ P.Višinskio 25, LT-5400 Šiauliai, Lithuania \\ e-mail:liukak@fm.su.lt,vilman@takas.lt \\ Lina MARKAUSKAITE \\ Institute of Mathematics and Informatics \\ Akademijos 4, 08663 Vilnius, Lithuania \\ e-mail:lmark@takas.lt \\ Received: March 2004
}

Abstract. This article analyses the informatics exam of secondary education in Lithuania. The research evaluates the correspondence of examination tasks to the exam program and its aims. Then, it studies the equality of examination variants. The article also discusses the clarity of the exam questions and instructions as well as the organization of the exam and the objectivity of evaluation criteria.

Key words: informatics, information and communication technology (ICT), secondary education, graduation exam, statistical analysis.

\section{Introduction}

New information and communication technologies (ICT) that are applied in various spheres of life are developing very rapidly. Knowledge and skills to use ICT gradually become the most important prerequisite for the work and life in the Information Society. Therefore, every person must gain the basic knowledge of informatics and must learn to use ICT according to his needs before graduating from the secondary school.

A number of researches analyse the problems of the evaluation of the ICT literacy (Eisenberg and Johnson, 1996; Bruce, 1998). In 1998 year, researchers I. Kirsch and others (1998) constructed and proposed the scales for the evaluation of ICT literacy. In 1986, F. Davis (1986) constructed a model for the analysis of person's capabilities to adopt and master new technologies. J. Lee (1986) developed a questionnaire for measuring the experience of computing.

In Europe, one of the most prevalent ICT literacy rating scales is ECDL (European Computer Driving License). It increasingly claims to become the world's standard ICDL (International Computer Driving License).

Lithuanian scientists like E. Telešius and A. Otas (1999), V. Denisovas and others (2001) analyse and try to evaluate the problems and validity of ECDL. V. Dagiene (2001), 
L. Markauskaitè (2001), D. Šaparnienè (2002), B. Bitinas (1998) and others study various other issues of computer literacy evaluation in their works too. This research carried out by the order of the National Examination Center seeks to put a foundation for the construction of a progressive evaluation system, which would motivate to introduce and apply new information technologies in the secondary curricula.

The ICT literacy of students and teachers is defined by the state's standards. The first step to check person's ICT skills is an informatics exam at the end of secondary school. Informatics examination covers the core course of informatics curriculum, which students learned in the following grades:

- 9 and 10 grades of lower secondary school; and

- 11 and 12 grades of upper secondary school (only the compulsory modules of informatics curriculum, i.e., the basic level of the course).

Informatics examination consists of two parts:

1. Independent creative task; and

2. Work with a computer: (a) theoretical and (b) practical tasks.

The aim of this study is to evaluate the correspondence of informatics examination tasks to the program and aims of the exam.

The research has the following objectives:

1. To analyse the correspondence of examination tasks to the examination program.

2. To estimate the equality of examination variants.

3. To study the perspicuity of examination tasks to students.

4. To discuss the organization of the examination.

5. To analyse the evaluation criteria.

The main object of the study is the material of the examination and all other relevant documentation.

The methods of the study are the analysis of the documents using the mathematical graph-tree technique and statistical analysis of the data.

The main hypothesis of the research is that the tasks of the informatics examination correspond to the program of the exam and realize its aims and objectives.

\section{The Correspondence between the Examination Tasks and its Program}

This part of the research studies the second part of informatics exam, i.e., work with a computer. Graph-tree technique (Ore, 1973) was applied for the analysis of the equivalency of the theoretical and practical examination tasks and the exam program. The examination program covered 37 topics (Table 1). Each task included one theoretical and two practical questions. Overall, six different variants of tasks were used in the exam. Graphs were drawn according to the topics of the questions. While evaluating the examination tasks, every question was given a coefficient of the correspondence to the particular topic of the examination program. If the question fully corresponded to the particular topic of 
Table 1

Correspondence of the informatics exam theoretical and practical questions to the exam program

\begin{tabular}{|c|c|c|c|c|c|c|c|}
\hline $\begin{array}{l}\text { Topics of the } \\
\text { exam program }\end{array}$ & 1 variant & 2 variant & 3 variant & 4 variant & 5 variant & 6 variant & Average \\
\hline 1. Hardware of the computer & $0 \%$ & $30 \%$ & $0 \%$ & $0 \%$ & $0 \%$ & $0 \%$ & $5 \%$ \\
\hline 2. Software of the computer & $0 \%$ & $0 \%$ & $0 \%$ & $0 \%$ & $10 \%$ & $0 \%$ & $1,7 \%$ \\
\hline 3. Computer networks & $100 \%$ & $0 \%$ & $20 \%$ & $10 \%$ & $20 \%$ & $0 \%$ & $25 \%$ \\
\hline $\begin{array}{l}\text { 4. Files and directories, ma- } \\
\text { naging and compressing } \\
\text { files }\end{array}$ & $0 \%$ & $50 \%$ & $10 \%$ & $0 \%$ & $0 \%$ & $0 \%$ & $10 \%$ \\
\hline $\begin{array}{l}\text { 5. The concept of computer- } \\
\text { based modelling }\end{array}$ & $0 \%$ & $0 \%$ & $0 \%$ & $0 \%$ & $10 \%$ & $0 \%$ & $1,7 \%$ \\
\hline $\begin{array}{l}\text { 6. Information security } \\
\text { in the computer }\end{array}$ & $0 \%$ & $0 \%$ & $0 \%$ & $0 \%$ & $10 \%$ & $0 \%$ & $1,7 \%$ \\
\hline 7. Evolution of the computer & $0 \%$ & $0 \%$ & $0 \%$ & $0 \%$ & $0 \%$ & $10 \%$ & $1,7 \%$ \\
\hline $\begin{array}{l}\text { 8. The concept of algorithm } \\
\text { and program }\end{array}$ & $0 \%$ & $0 \%$ & $0 \%$ & $0 \%$ & $0 \%$ & $0 \%$ & $0 \%$ \\
\hline 9. Programming languages & $0 \%$ & $0 \%$ & $0 \%$ & $0 \%$ & $0 \%$ & $0 \%$ & $0 \%$ \\
\hline 10. The concept of data & $0 \%$ & $0 \%$ & $0 \%$ & $0 \%$ & $0 \%$ & $0 \%$ & $0 \%$ \\
\hline $\begin{array}{l}\text { 11. Main controlling com- } \\
\text { mands (sequence of state- } \\
\text { ments, conditional and re- } \\
\text { peat statements) }\end{array}$ & $0 \%$ & $0 \%$ & $0 \%$ & $0 \%$ & $0 \%$ & $0 \%$ & $0 \%$ \\
\hline $\begin{array}{l}\text { 12. The style and culture of } \\
\text { algorithm }\end{array}$ & $0 \%$ & $0 \%$ & $0 \%$ & $0 \%$ & $0 \%$ & $0 \%$ & $0 \%$ \\
\hline 13. The steps of solving tasks & $0 \%$ & $0 \%$ & $0 \%$ & $0 \%$ & $0 \%$ & $0 \%$ & $0 \%$ \\
\hline $\begin{array}{l}\text { 14. Classification of informa- } \\
\text { tion }\end{array}$ & $0 \%$ & $0 \%$ & $30 \%$ & $0 \%$ & $0 \%$ & $0 \%$ & $5 \%$ \\
\hline 15. Information processes & $100 \%$ & $0 \%$ & $30 \%$ & $10 \%$ & $0 \%$ & $20 \%$ & $26,7 \%$ \\
\hline $\begin{array}{l}\text { 16. Information storages and } \\
\text { sources }\end{array}$ & $0 \%$ & $100 \%$ & $20 \%$ & $0 \%$ & $10 \%$ & $0 \%$ & $21,7 \%$ \\
\hline 17. Discretion of information & $10 \%$ & $0 \%$ & $0 \%$ & $0 \%$ & $0 \%$ & $0 \%$ & $1,7 \%$ \\
\hline $\begin{array}{l}\text { 18. Encoding of informa- } \\
\text { tion: characters; alpha- } \\
\text { bets; character sets; bi- } \\
\text { nary system }\end{array}$ & $0 \%$ & $0 \%$ & $0 \%$ & $0 \%$ & $0 \%$ & $0 \%$ & $0 \%$ \\
\hline $\begin{array}{l}\text { 19. Information processing } \\
\text { (text, figures, graphs, } \\
\text { sounds) }\end{array}$ & $25 \%$ & $25 \%$ & $15 \%$ & $15 \%$ & $15 \%$ & $15 \%$ & $18,3 \%$ \\
\hline $\begin{array}{l}\text { 20. Main possibilities of } \\
\text { graphics editor }\end{array}$ & $0 \%$ & $0 \%$ & $0 \%$ & $0 \%$ & $0 \%$ & $0 \%$ & $0 \%$ \\
\hline $\begin{array}{l}\text { 21. The concept of informa- } \\
\text { tion and communication } \\
\text { technology }\end{array}$ & $50 \%$ & $10 \%$ & $20 \%$ & $10 \%$ & $100 \%$ & $10 \%$ & $38 \%$ \\
\hline $\begin{array}{l}\text { 22. Juridical aspects of infor- } \\
\text { mation }\end{array}$ & $0 \%$ & $0 \%$ & $0 \%$ & $0 \%$ & $10 \%$ & $0 \%$ & $1,7 \%$ \\
\hline $\begin{array}{l}\text { 23. The concept of informa- } \\
\text { tion society }\end{array}$ & $0 \%$ & $0 \%$ & $0 \%$ & $0 \%$ & $0 \%$ & $100 \%$ & $16,7 \%$ \\
\hline
\end{tabular}




\begin{tabular}{|c|c|c|c|c|c|c|c|}
\hline $\begin{array}{l}\text { Topics of the } \\
\text { exam program }\end{array}$ & 1 variant & 2 variant & 3 variant & 4 variant & 5 variant & 6 variant & Average \\
\hline $\begin{array}{l}\text { 24. The advantages of text } \\
\text { processing with the com- } \\
\text { puter }\end{array}$ & $0 \%$ & $0 \%$ & $0 \%$ & $0 \%$ & $0 \%$ & $0 \%$ & $0 \%$ \\
\hline 25. Main elements of the text & $100 \%$ & $100 \%$ & $100 \%$ & $100 \%$ & $100 \%$ & $100 \%$ & $100 \%$ \\
\hline $\begin{array}{l}\text { 26. Main operations with the } \\
\text { word processing applica- } \\
\text { tions }\end{array}$ & $100 \%$ & $100 \%$ & $100 \%$ & $100 \%$ & $100 \%$ & $100 \%$ & $100 \%$ \\
\hline 27. Creating tables & $100 \%$ & $100 \%$ & $100 \%$ & $100 \%$ & $100 \%$ & $100 \%$ & $100 \%$ \\
\hline 28. Formatting documents & $100 \%$ & $100 \%$ & $100 \%$ & $100 \%$ & $100 \%$ & $100 \%$ & $100 \%$ \\
\hline 29. Printing documents & $100 \%$ & $100 \%$ & $100 \%$ & $100 \%$ & $100 \%$ & $100 \%$ & $100 \%$ \\
\hline 30. Saving documents & $100 \%$ & $100 \%$ & $100 \%$ & $100 \%$ & $100 \%$ & $100 \%$ & $100 \%$ \\
\hline $\begin{array}{l}\text { 31. Editing the digital infor- } \\
\text { mation using the spread- } \\
\text { sheet }\end{array}$ & $100 \%$ & $100 \%$ & $100 \%$ & $100 \%$ & $100 \%$ & $100 \%$ & $100 \%$ \\
\hline $\begin{array}{l}\text { 32. Main operations with the } \\
\text { spreadsheet (create a new } \\
\text { table; create a chart) }\end{array}$ & $55 \%$ & $55 \%$ & $55 \%$ & $55 \%$ & $55 \%$ & $55 \%$ & $55 \%$ \\
\hline 33. The concept of data base & $0 \%$ & $60 \%$ & $0 \%$ & $0 \%$ & $0 \%$ & $0 \%$ & $10 \%$ \\
\hline 34. The Internet & $70 \%$ & $40 \%$ & $40 \%$ & $40 \%$ & $0 \%$ & $10 \%$ & $33,3 \%$ \\
\hline 35. Searching the Internet & $50 \%$ & $0 \%$ & $100 \%$ & $0 \%$ & $0 \%$ & $0 \%$ & $25 \%$ \\
\hline 36. E-mail & $70 \%$ & $0 \%$ & $0 \%$ & $100 \%$ & $0 \%$ & $0 \%$ & $28,3 \%$ \\
\hline $\begin{array}{l}\text { 37. The concept of hypertext } \\
\text { and multimedia }\end{array}$ & $0 \%$ & $10 \%$ & $0 \%$ & $0 \%$ & $0 \%$ & $0 \%$ & $1,7 \%$ \\
\hline
\end{tabular}

the exam program, $100 \%$ coefficient of the correspondence was given. If only minimal knowledge of this topic was needed, only $5 \%$ or $10 \%$ coefficient was given. Nine experienced teachers accomplished the evaluation of the correspondence. The average results of the evaluation of all variants are shown in Table 1. We will analyse the results of the evaluation.

As we can see, the least attention is paid to the following topics of the exam's program:

1. Hardware of the computer.

2. Software of the computer.

3. The concept of computer-based modelling.

4. Information security in the computer.

5. Evolution of the computer.

6. The concept of algorithm and program.

7. Programming languages.

8. The concept of data.

9. Main controlling commands: sequence of statements, conditional and repeat statements.

10. The style and culture of algorithm. 
11. The steps of solving tasks.

12. Classification of information.

13. Discretion of information.

14. Encoding of information: characters; alphabets; character sets; binary system.

15. Main possibilities of graphics editor.

16. Juridical aspects of information.

17. The advantages of text processing with the computer.

18. The concept of hypertext and multimedia.

The average percentage of their usage is $0 \%-10 \%$.

Another group consists of the topics having the correspondence coefficient between $10 \%$ and $50 \%$ :

1. Computer networks.

2. Files and directories, managing and compressing files.

3. Information processes.

4. Information storages and sources.

5. Information processing (text, figures, graphs and sounds).

6. The concept of information society.

7. The concept of database.

8. The Internet.

9. Searching the Internet.

10. E-mail.

These topics were directly associated with the subject of theoretical questions, or the knowledge of these topics were necessary to solve the tasks. Some tasks required certain practical skills.

Most common topics in the examination papers were connected to the text processing skills and effective usage of spreadsheets. In all variants of practical tasks students had to demonstrate their practical skills and theoretical knowledge of spreadsheets and word processors. The following topics had the correspondence coefficient of $100 \%$ :

1. Main elements of the text.

2. Main operations with the word processing applications.

3. Creating tables.

4. Formatting documents.

5. Printing documents.

6. Saving documents.

7. Editing the digital information using the spreadsheet. 
Only the topic "Main operations with the spreadsheet" had the correspondence of $55 \%$. Considering the results and having analysed the second part of the exam, we can state that the theoretical and practical questions given in the examination papers correspond to the exam program (an average coefficient is $27,83 \%$ ). However, the questions lack variety, the range of assessed knowledge and skills is narrow. The exam mostly checked students' abilities to work with word processors and spreadsheets. Knowledge on such themes as file management, information processing, e-mail, computer logic and application of other software tools is used very little or not checked at all.

\section{Perspicuity of Exam's Instructions and Questions}

The first part of the informatics exam is an independent creative task. A student must create a program or other applied work using ICT. He or she must demonstrate skills, which he/she gained during the lessons of informatics or learned independently. A creative task is done under the supervision of a teacher.

While studying comprehensibility of the instructions, we can see that a creative task is formulated clearly and reasonably. Students and teachers know clearly what they have to do. They do not have any misunderstandings. Students are given examples of creative works.

However, it is quite difficult to analyse the evaluation of this part of the exam, since there are almost no possibilities to review the topics and other aspects of creative works produced by the students. In general, a certain plan and clear definition of initial conditions are necessary to accomplish any sound and fully developed modern applied work. A work presented with the plan or logical structure and the description of initial conditions will make a student and a teacher think on presenting the work to the user in understandable and logical way. A computer program or other ICT-based application cannot be presented without such a scheme and a description of initial conditions. However, there is no such a requirement in the instructions of the independent creative task. The definition of the task and the process of the implementation are left to the teacher's competence and not assessed. As a result, the evaluation of creative task may differ in various schools. For instance, a primitive creative work may get the maximal score in one school while only the minimal score in another.

The questions in the second part of the exam (all 6 variants) are formulated clearly and without ambiguities:

- Theoretical questions are easily understandable and correspond the requirements of modern information culture.

- The first practical task asks to draw a simple table. It does not cause any misunderstanding. Students do not have any difficulties.

- The second practical task is to create an electronic table with a spreadsheet. The task is presented clearly, some variants (i.e., 1, 2, 3 and 6) have even formulas. Some uncertainties are in variants 4 and 5. In both variants the tasks do not explain clearly where and how to use given numbers (i.e., to use them as data or write directly into formulas). 
The second part of the exam required not only theoretical and practical skills but also ability to type prompt, what is not the most important skill of informatics.

\section{Analysis of the Order of the Examination}

The first part of the exam is an individual task. It is not compulsory to do this creative task under permanent supervision of informatics teacher in a computer room. This means that a student may unfairly use the abilities of other people and to present a borrowed work as his own after having learned to defend it.

Teachers who have no connection with informatics or computers supervise the second part of the exam. A student accomplishes all tasks, copies the results into a floppy disk, brings it to the computer with the printer, and prints the results. However, a student may copy its work into the computer and another student may use it.

\section{Analysis of Evaluation Criteria}

A creative task gives 30 points (10 for the description, 20 for the work itself and presentation). A thorough instruction is given concerning the evaluation of each part. It is stated how many points to give for each quality element. However, the instruction does not specify the size and complexity of the work. In addition, it is not directed what kind of ICT to use. Some works may not require structural algorithmic thinking. Thus, the complexity of a creative work may vary considerably: it could be a new serious program as well as series of plain slides or a simple report. Different teachers' attitude may cause subjective evaluation. Some teachers appreciate programming, some others the ability to use general-purpose software. So, the independent creative tasks could be evaluated not equally.

The tasks of the second part (6 variants) have a strict evaluation structure and criteria. Therefore, this part is evaluated objectively. There is only one drawback is in the evaluation of the theoretical task. This task is given 30 points. Ten points out of them is given to the shaping of the answer. However, the requirements for the layout of the text are not provided in the task. The evaluation criteria of practical questions are detailed, logical, and clear.

\section{The Evaluation of Equality of Variants}

On the basis of the correspondence of the tasks and examination program, a statistical study was accomplished. Common descriptive statistic methods together with correlation analysis were applied in order to evaluate the relation between attributes. Regression analysis was applied to predict the dependence of one variable on the others (Čekanavičius and Murauskas, 2000; 2002). A linear regression model was used. Correlation $(r)$ and determination $\left(r^{2}\right)$ coefficients that describe correlation and functional dependence 
of each variant were calculated. Each variant was compared to each other in order to find the coefficients of linear dependence functions. The following linear regression equations and coefficients were obtained:

$$
\begin{array}{lll}
V_{1}=V_{2} * 0.683+12.466, & r=0.648, & r^{2}=0.42, \\
V_{1}=V_{3} * 0.896+8.051, & r=0.835, & r^{2}=0.697, \\
V_{1}=V_{4} * 0.889+10.665, & r=0.846, & r^{2}=0.715, \\
V_{1}=V_{5} * 0.816+12.524, & r=0.77, & r^{2}=0.592, \\
V_{1}=V_{6} * 0.753+14.509, & r=0.716, & r^{2}=0.521, \\
V_{2}=V_{3} * 0.804+6.928, & r=0.792, & r^{2}=0.627, \\
V_{2}=V_{4} * 0.776+9.674, & r=0.779, & r^{2}=0.607, \\
V_{2}=V_{5} * 0.906+8.578, & r=0.86, & r^{2}=0.74, \\
V_{2}=V_{6} * 0.768+10.3, & r=0.77, & r^{2}=0.593, \\
V_{3}=V_{4} * 0.802+7.737, & r=0.819, & r^{2}=0.671, \\
V_{3}=V_{5} * 0.820+7.272, & r=0.831, & r^{2}=0.69, \\
V_{3}=V_{6} * 0.796+8.326, & r=0.811, & r^{2}=0.658, \\
V_{4}=V_{5} * 0.839+4.089, & r=0.832, & r^{2}=0.693, \\
V_{4}=V_{6} * 0.828+4.814, & r=0.827, & r^{2}=0.684, \\
V_{5}=V_{6} * 0.833+4.692, & r=0.839, & r^{2}=0.703,
\end{array}
$$

where $V_{1} \ldots V_{6}$ - variant No. 1 . .variant No. 6 of the examination task.

The correlation coefficients vary between 0.648 and 0.86 , and determination between 0.42 and 0.74 . Therefore, with probability of 0.95 we can state that tasks in all variants are equal, because a moderate inter-subordination was estimated.

\section{Evaluation of the Difficulty of Tasks According to the Results of Examination}

The statistics of informatics exam given in Fig. 1 show that grades of the exam do not correspond to the standard normal requirements. They turn to be better.

On the basis of this data and the material given in Table 1, we can conclude that tasks are too easy; they differentiate students' grades too little. On the other hand, quite a big influence had a creative task (30\%), and we have no possibilities to review its evaluation, but we can suppose that the grades are quite high.

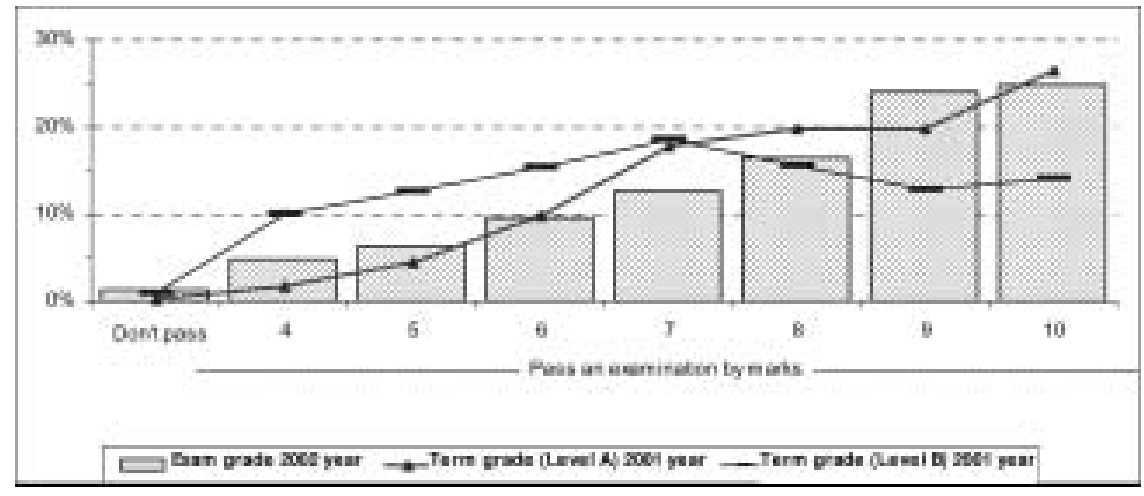

Fig. 1. General statistics of informatics examination: students' exam and term grades. 


\section{Conclusions}

Having analysed the correspondence of informatics exam to the requirements of examination program and general aims of informatics subject we came to the following conclusions:

1. The tasks of informatics exam correspond to the program of examination.

2. The exam helps to check the main students' ICT skills.

3. Examination tasks and instructions are clear and understandable to students.

4. The organization of the examination may influence students' grades (i.e., a creative work may be fulfilled not independently; a teacher not knowing how to work with the computer may not notice students' dishonest works during the second part of the exam).

5. Evaluation criteria allow evaluating students' knowledge and skills objectively.

6. The tasks of all six variants are equal.

7. The practical tasks of the second part of the exam and the independent creative task differentiate students' grades too little.

\section{Acknowledgements}

The analysis is carried out by the order of the National Examination Center.

\section{References}

Bitinas, B. (1998). Ugdymo tyrimų metodologija (in Lithuanian, Methodology of Educational Research) Jošara, Vilnius.

Bruce, B.C. (1998). Current issues and future directions. In J. Flood, S.B. Heath and D. Lapp (Eds.), Handbook of Research on Teaching Literacy through the Communicative and Visual Arts. Simon \& Schuster Macmillan, New York, pp. 875-884.

Čekanavičius, V., and G. Murauskas (2000). Statistika ir jos taikymai, I (in Lithuanian, Statistics and its Applications. Part I). TEV, Vilnius.

Čekanavičius, V., and G. Murauskas (2002). Statistika ir jos taikymai, II (in Lithuanian, Statistics and its Ap plications. Part II). TEV, Vilnius.

Dagiené, V. (2001). Bendrojo lavinimo mokykos informatikos turnio palyginimas su Europos kompiuteriu varotojų standartu (in Lithuanian, A comparison of informatics curriculum for general education with ECDL standard). Informatikos mokslai. Mokslo darbai, 18, 25-30.

Davis, F. (1986). A Technology Acceptance Model for Empirically Testing New End-User Information Systems: Theory and Results. Doctoral dissertation. Massachusetts Institute of Technology, USA.

Denisovas, V., S. Maciulevičius, A. Otas, V. Šakalys, E. Telešius, A. Vidžiūnas and A. Žandaris (2001). Kompiuterinis raštingumas: ECDL pradmenys (in Lithuanian, Computer Literacy: ECDL Start). Žara, Vilnius.

Eisenberg, M., and D. Johnson (1996). Computer skills for information problem solving: learning and teaching technology in context. ERIC Digest, EDIR 055809.

Kirsch, I., J. Jamieson, C. Taylor and D. Eignor (1998). Computer Familiarity among TOEFL Examinees. TOEFL Research Report 59, Educational Testing Service.

Lee, J. (1996). The effects of past computer experience on computerized aptitude test performance. Educational and Psychological Measurement, 26, 727-733. 
Markauskaite, L. (2001). PLSpath modelling of various factors' influence on students' knowledge of informatics. Informatica, 12(3), 413-430.

Ore, O. (1973). Grafai ir ju pritaikymas (in Lithuanian, Graphs and their Application). Mintis, Vilnius.

Šaparnienė, D. (2002). Raštingumas ir kompiuterinis raštingumas: apibrèžtis ir istorinis kultūrinis kontekstas (in Lithuanian, Literacy and computer literacy: a definition and ethno-cultural context). Pedagogika, 61, 175-180.

Telešius, E., and A. Otas (1999). ECDL programos startas Lietuvoje: pirmieji žingsniai ir nuotolinio mokymo perspektyvos (in Lithuanian, The Start of ECDL Program in Lithuania: the First Steps and the Perspectives of Distant Training). In The Role of ODL in the Information Society. Technologija, Kaunas, pp. 155-160. 
L. Kaklauskas is a lector at the Department of Computer Science of Šiauliai University. Major research interests are methodology of traditional learning of informatics, distance learning aiming, implementation of information technology in education. $\mathrm{He}$ represents Šiauliai University in LieDM (real time videoconferencing network) project from 1998 and analyzes possibilities of distance learning in Šiauliai region. With V. Narkienè he guides a club of Šiauliai for IT teachers (www.su.lt/ik). He also a teacher-methodologist of IT.

V. Narkienè is an assistant at the Department of Computer Science of Šiauliai University. Her major research interests are implementation of information technology in education. With L.Kaklauskas she guides a club of Šiauliai for IT teachers (www. su . lt/ik). She is a teacher methodologist of IT.

L. Markauskaite is a research fellow of the Institute of Mathematics and Informatics, in Lithuania. She received a PhD in Informatics in 2000. Her major research interests are qualitative and quantitative research and data analysis, development of ICT literacy, cross-national strategies and practices of ICT introduction into secondary school as well as all other aspects of ICT implementation into education. Her interests also include the issues of telecommunications market liberalization, provision of universal telecommunications services, and Information Society development. 


\section{Informatikos egzamino Lietuvos bendrojo lavinimo mokykloje analizė Liudvikas KAKLAUSKAS, Vilma NARKIENĖ, Lina MARKAUSKAITĖ}

Pasaulio mokslinèje literatūroje galima rasti visą eilę darbų, analizuojančių kompiuterinio raštingumo problemas - tai M. Eisenberg ir D. Johnson (1996), C. Bruce (1998) ir kitų darbai. Kuriamos patikimos raštingumo îvertinimo skalès. Pirmasis Lietuvos piliečio informaciniu gebejjimu patikrinimo etapas yra mokyklinis informatikos egzaminas. Šio straipsnio tikslas - ivertinti informatikos egzamino užduočių atitiktį informatikos egzamino programai bei išanalizuoti, ar informatikos egzamino užduotys igyvendino egzamino programos keliamus tikslus ir uždavinius. Išanalizuoti vertinimo kriterijus ir įvertinti egzamino užduočiu variantu lygiavertiškumą. Atliekant egzamino užduočiu atitikimo egzamino programai analizę buvo brěžiami grafai pagal analizuojamą tematiką. Kiekviena užduotis įvertinta atitikimo egzamino programai koeficientu, jei užduotis ir programos punktas pilnai sutampa - skiriamas 100\% atitikties koeficientas, jei atliekant užduoti reikès tik minimaliu žinių - 5\% arba $10 \%$ koeficientas. Analizès rezultatai rodo, kad dažniausiai egzamino medžiagoje sutinkamos temos buvo susietos su teksto tvarkymo igūdžiais bei efektyviu skaičiuoklès naudojimu.

Užduočiu lygiavertiškumo ivertinimui, pagal sudaryta egzaminu programos ir užduočiu atitikties įvertinimo lentelę, atlikta statistinè duomenu analizè. Buvo skaičiuojami koreliacijos $(r)$ bei determinacijos $\left(r^{2}\right)$ koeficientai, braižomi grafikai, nusakantys kiekvieno varianto pateikiamos medžiagos tarpusavio sutapimą ir funkcinę priklausomybę. Apskaičiuoti koreliacijos koeficientai kinta nuo 0,648 iki 0,86, o determinacijos - nuo 0,42 iki 0,74, todèl su 0,95 tikimybe galima teigti, kad visų variantu užduotys yra lygiavertès, nes tarp jų yra nustatyta vidutiniška tarpusavio priklausomybè.

Tyrimu rezultatai rodo, kad užduotys atitinka informatikos egzamino programa, moksleiviams jos aiškios ir suprantamos, egzamino variantai yra lygiaverčiai, tačiau egzamino organizavimo tvarka gali įtakoti moksleiviu įvertinimus (mokytojas, nemokantis dirbti kompiuteriu, gali nepastebèti nesą̌iningos moksleiviụ veiklos, kūrybinė užduotis gali būti atliekama nesavarankiškai). Egzamino vertinimo kriterijai iš esmès objektyviai ivertina moksleivio žinias ir gebejjimus, tačiau reikètụ vengti dviprasmybiu bei neapibrě̌tumų. Deja, pagal rezultatus matyti, kad egzaminas per mažai diferencijuoja egzaminą laikiusiujų moksleivių įvertinimus. 